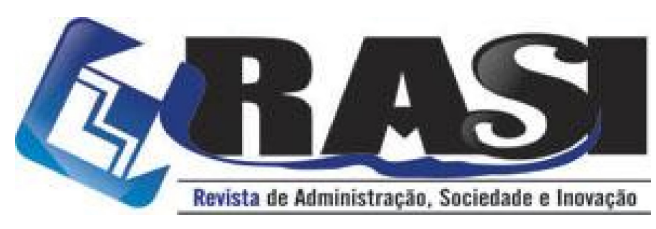

http://www.rasi.vr.uff.br

RASI, Volta Redonda/RJ, v. 6, n. 2, pp. 112-133, mai./ago. 2020

\title{
Entrepreneurial Strategies and Innovative Strategies: Bibliometric review, concepts, models and future investigations
}

Juliana Carvalho de Sousa (Universidade Potiguar) - juli.cs1009@gmail.com

Luiz Antônio Felix Júnior (Universidade Potiguar e Instituto Federal de Alagoas) -luiz.felix@ifal.edu.br Wênyka Preston Leite Batista da Costa (Universidade Potiguar e Universidade Estadual do Rio Grande do Norte) - wenykapreston@hotmail.com

Kleber Cavalcanti Nobrega (Universidade Potiguar) - klebercn@unp.br

\begin{abstract}
The research centered on mapping an international production about entrepreneurial and innovative strategies, in the time search period from 2008 to 2018. It comprises a bibliometric research performed in the Web of Science database. By analyzing such works, concepts of entrepreneurial strategy and models, types, trends and gaps related to the entrepreneurial strategy and the innovative strategy were observed. The following study trends can be emphasized: innovation, internationalization, family companies, entrepreneurship, innovative strategies, social responsibility, environmental innovation, among others; and gaps such as the investigation on the relationship between the attributes of top management and the development of entrepreneurial strategies; the verification of a new scale in order to improve the instrument measurement between cultures; the collection of macroeconomic data in order to develop a broad model of evaluation to develop effective strategies in the current market and environmental innovation in the company's global strategy.
\end{abstract}

Keywords: Entrepreneurial strategies. Innovative strategies. Innovation. Entrepreneurship. bibliometric research. Web of Science.

\section{Estratégias Empresariais e Estratégias Inovadoras: Revisão sistemática, conceitos, modelos e investigações futuras}

\section{Resumo}

A pesquisa centrou-se no mapeamento de uma produção internacional sobre estratégias empreendedoras e inovadoras, no período de pesquisa de 2008 a 2018. Compreende uma pesquisa bibliométrica realizada no banco de dados Web of Science. Ao analisar tais trabalhos, foram observados conceitos de estratégia e modelos empreendedores, tipos, tendências e lacunas relacionadas à estratégia empreendedora e à estratégia inovadora. As seguintes tendências de estudo podem ser enfatizadas: inovação, internacionalização, empresas familiares, empreendedorismo, estratégias inovadoras, responsabilidade social, inovação ambiental, entre outras; e lacunas, como a investigação sobre a relação entre os atributos da alta gerência e o desenvolvimento de estratégias empresariais; a verificação de uma nova escala para melhorar a medição do instrumento entre culturas; a coleta de dados macroeconômicos, a fim de desenvolver um amplo modelo de avaliação para desenvolver estratégias efetivas no mercado atual e a inovação ambiental na estratégia global da empresa.

Palavras-chave: Estratégias empreendedoras. Estratégias inovadoras. Inovação. Empreendedorismo. Pesquisa bibliométrica. Web of Science.

\section{S. Universidade \\ Fluminense}

R. Desembargador Ellis Hermydio Figueira, 783, Bloco A, sl. 218, Aterrado. 27213-415 - Volta Redonda, RJ - Brasil

www.uff.br

Copyright (c) 2020 RASI. Todos os direitos, até mesmo de tradução, são reservados. É permitido citar parte de artigos sem autorização prévia, desde que seja identificada a fonte. 


\section{Entrepreneurial Strategies and Innovative Strategies: Bibliometric review, concepts, models and future investigations}

Introduction

In the current context, the organization's skill to progressively adapt to its environment is a central aspect within the strategic management involving decisions, besides succeeding in the elaboration and execution of strategies aiming at reaching organizational objectives (Tondolo, Bitencourt and Tondolo, 2011). Such management can be regarded as a process of operations' guidelines which can generate value for society (Aslund and Backstrom, 2017). In relation to strategy, such acceptance is defined as procedures that lead the organizations with the objective to assign them a competitive advantage in order to reach the ideal performance (Prodromos, et al., 2011; Cruz et al., 2018).

For such, it is necessary that the organisations present entrepreneurial and innovative features in order to ensure room in this area (Gomes, 2014). In the second edition of "The Theory of Economic Development", Schumpeter (1982) associated entrepreneurship with innovation. The image of an entrepreneur was seen as an economic agent who was able to insert new products in the market based on technological innovations. From then on, innovating was considered an essential strategy to reach the organizational development and growth.

As for the innovation construct, which involves the interaction between actors, network, organization and institutions, it only started to be worked on more deeply from the 1990's (Janssen and Moors, 2013). Innovation is conceptualized as "something new" which is able to supply the consumers and the organization with benefits (Maculan, 2005). Such concept brings up an idea that will be able to succeed and it can't be considered only as the production of a new good. It is from innovation that a sustainable development and an element of differentiation in relation to the competitiveness can be generated (Velasquez, Dalla Santa and Dias, 2016). This way, innovation management comes up as a fundamental activity that supports the enterprises' growth and survival (Wang and Juan, 2016), assisting entrepreneurs as business opportunities (Severo et al., 2019).

Based on that, there are some types of strategies, like the entrepreneurial and the innovative ones. According to Tondolo, Bitencourt and Tondolo (2011), and considering that entrepreneurship involves creation and strategy focuses on maintaining the competitive advantage, and both constructs have value creation as the intersection spot, then, there are the entrepreneurial strategies. As for the innovative strategies, they are conceptualized as necessary, so as to generate an advantage when it comes to costs, revenue increase and flexibility (Spekman and Davis, 2016). These strategies are the results of the combination of new products' creation methods and value delivery focused on a technological approach (Narasimhan, Kull and Nahm, 2012).

In their studies, Alves, Galina \& Dobelin (2016), Dagnino et al. (2015) \& Yeo et al. (2015) approached a bibliometric analysis about the conceptual strategies around innovation. As for the bibliometric studies which involve entrepreneurial strategies, there are scholars like Brancher, Oliveira \& Roncon (2012), who developed a meta-analysis in articles published in the National Association Meeting of Administration Post-Graduation and Research (EnANPAD) between 2004 and 2008 about the topic, highlighting guidelines for new researches in their results. The study by Ávila et al. (2014) can also be emphasized. It focuses on bibliometric studies from the Web of Science database about entrepreneurship and social 
entrepreneurship from 2002 to 2011. This way, this research's gap focuses on the topic's bibliometric exploration, entrepreneurial strategies and innovative strategies in the past ten years, involving the Web of Science database.

Based on that, the following research question comes to mind: what is there in literature about entrepreneurial strategies, innovative strategies and their possible interfaces encompassing concepts, evolution, gaps and trends?

This way, this study's objective focused on mapping the international production about the "entrepreneurial strategies and innovative strategies" theme, analyzing their topics and possible interfaces.

This bibliometric analysis contributes to the topic's conceptualization, the progress observation on the studies developed in the area, assisting with comprehension, as well as the identification of trends and gaps, bringing some light on new emerging themes when it comes to the topic analyzed.

\section{Methodology}

Trying to reach the objective intended in the investigation, a bibliometric study was performed. The database chosen for the development of the study was the ISI Web of Science (WoS), which is considered a multidisciplinary indexing source, which gathers renowned periodicals (Oliveira, Rodrigues and Matias, 2017; Ceretta, Reis and Rocha, 2016). As for the data collection procedures, the search period used was from 2008 to 2018, totalling 10 full years and 5 months (considering the current year of 2018).

As a search criterion, the following key words were adopted: "innovative* strategy*", "strategy* of innovation", "entrepreneurial* strategy*", "entrepreneurial* and innovative* strategy*". An asterisk (*) was used to include possible plural words, and quotes (")") were used for research accuracy. As for the words "entrepreneurial* and innovative* strategy*, there were no articles, which may mean that no interfaces on these topics were found in the research database.

The sample identification was performed by searching these topics in the articles' title, abstracts and key words.

After the search, the following filters were applied: type of document, from which article and review were selected; "Business", "Management" and "Business finance" were chosen as areas of study. The reason for choosing such areas was the proximity with the administration scientific field and, then, the language filter was refined, including only articles written in the English language, according to Table 1.

Table 1. Procedures adopted, by key-word, for research sample refinement.

\begin{tabular}{lrrrrr}
\hline \multicolumn{1}{c}{ Filters } & $\begin{array}{c}\text { "innovative* } \\
\text { strategy*" }\end{array}$ & $\begin{array}{c}\text { "strategy* of } \\
\text { innovation" }\end{array}$ & $\begin{array}{c}\text { "entrepreneurial* } \\
\text { strategy*" }\end{array}$ & $\begin{array}{c}\text { "entrepreneurial* and } \\
\text { innovative* strategy*" }\end{array}$ & Total \\
\hline Key words & 892 & 29 & 63 & 0 & 984 \\
\hline $\begin{array}{l}\text { Types of work: } \\
\text { and } \\
\text { review }\end{array}$ & 705 & 5 & 47 & 0 & 757 \\
\hline $\begin{array}{l}\text { Areas: Business, } \\
\text { Management, and } \\
\text { Business finance }\end{array}$ & 17 & 3 & 23 & 0 & 43 \\
\hline $\begin{array}{l}\text { Language } \\
\text { (English) }\end{array}$ & 14 & 3 & 23 & 0 & 40 \\
\hline
\end{tabular}

It should be emphasized that other areas of knowledge were identified through the research, such as: engineering electrical electronic (58); materials science multidisciplinary 
(57); chemistry multidisciplinary (56); biochemistry molecular biology (44); nanoscience nanotechnology (42), among others. However, these areas were discarded since the article clipping focused only on the administration field.

Thus, with this refinement, 40 works were identified, and from then their bibliometric analysis took place followed by a further bibliometric analysis in 20 articles, which discussed the topic consistently. The choice of the 20 articles for a more detailed analysis was due to the fact that not all the works identified dealt with the theme of innovative and entrepreneurial strategy as a central objective, thus giving attention to those most relevant to the theme.

It is important to highlight that this study used the VOS viewer software with the objective to identify clusters that demonstrate the trend of the researches related to the entrepreneurial strategy and innovative strategy.

\section{Bibliometric Results}

The first bibliometric analysis' observation refers to the number of publications by year, according to Chart 1 .

Chart 1.Publications on entrepreneurial strategy and innovative strategy by year.

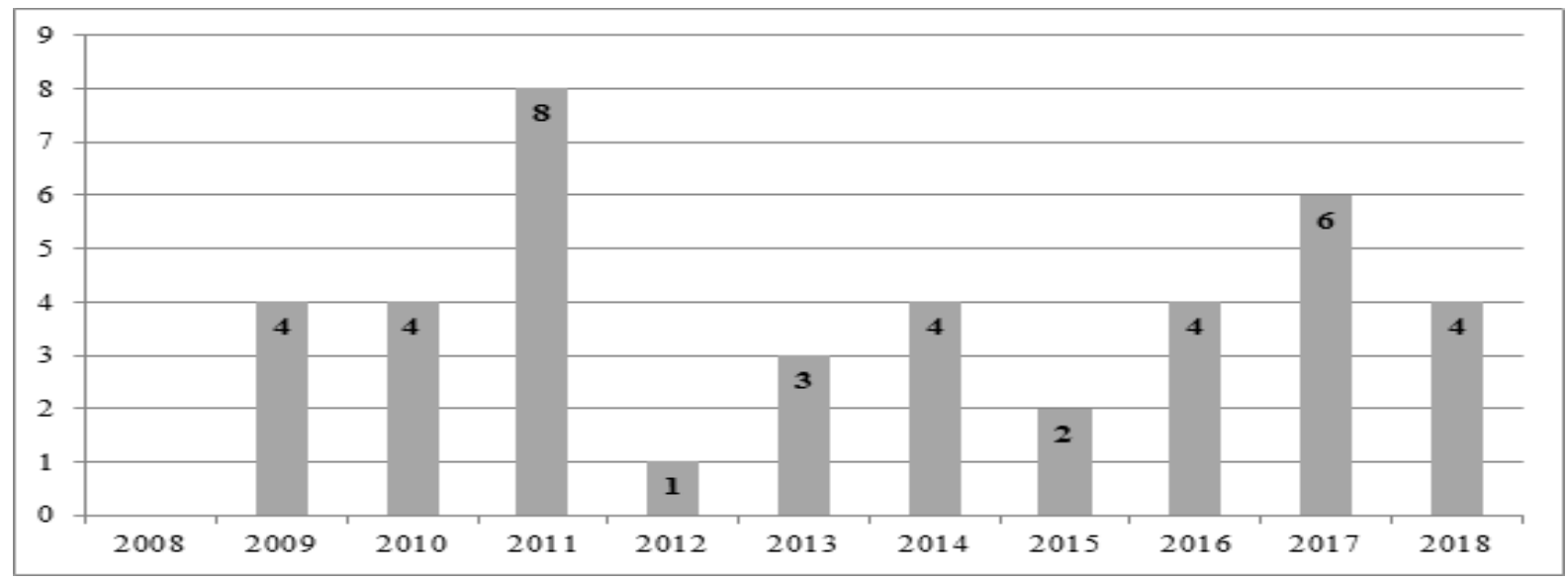

It should be noted that in 2008 there was no publication and the year 2012 presents only one publication that refers to the pre-entrepreneurship architecture effect in organisational results (Urban, 2012). The remaining time periods had an average of four publications. Then, there is the Top 10 on the number of article publications by country, according to Table 2 .

Table 2.Top 10 of the article publications by authors' institutions' country of origin.

\begin{tabular}{cccc}
\hline & Country & Number & $\mathbf{\%}$ \\
\hline 1 & Estados Unidos & 9 & 17,3 \\
2 & Inglaterra & 6 & 11,5 \\
3 & Austrália & 3 & 5,8 \\
4 & Índia & 3 & 5,8 \\
5 & Africa do Sul & 3 & 5,8 \\
6 & Canadá & 3 & 5,8 \\
7 & Taiwan & 3 & 5,8 \\
8 & Espanha & 2 & 3,8 \\
9 & Itália & 2 & 3,8 \\
10 & Emirados Árabes Unidos & 2 & 3,8 \\
\hline Total & & $\mathbf{3 6}$ & $\mathbf{6 9 , 2}$ \\
\hline
\end{tabular}


In this aspect, the countries with the highest percentage were the United States (17\%) and England $(11.5 \%)$. These percentages can be explained since both countries were considered as a reference when it comes to innovation and entrepreneurship. As for innovation, according to the Global Innovation Index (2017) report, elaborated by the Cornell University, by the Instead Business School and by the World Intellectual Property Organisation, the United States and England rank fourth and fifth places, respectively, out of the world's most innovative countries. In this case, the United Kingdom includes England, which is one of their nations. As for entrepreneurship, the United States ranked first on the Global Entrepreneurship Index (2017) and the United Kingdom ranked fourth. This study was promoted by The Global Entrepreneurship and Development Institute organisation.

Table 3 shows the Top 10 of the mostly cited publications. According to the ranking, the publication with the highest number of citations was the study by Steffens, Davidsson and Fitzsimmons (2009).

Table 3. Top 10 of the mostly cited publications.

\begin{tabular}{|c|c|c|c|c|}
\hline & Title & Authors & Journals & $\begin{array}{l}\text { Citation in } \\
\text { Web of } \\
\text { Science }\end{array}$ \\
\hline 1 & $\begin{array}{l}\text { Performance configurations Over time: } \\
\text { implications for growth- and profit-oriented } \\
\text { strategies. }\end{array}$ & $\begin{array}{l}\text { Steffens, Davidsson e } \\
\text { Fitzsimmons (2009) }\end{array}$ & $\begin{array}{l}\text { Entrepreneurship } \\
\text { Theory and } \\
\text { Practice }\end{array}$ & 64 \\
\hline 2 & $\begin{array}{l}\text { Diagnosing a firm's internal environment for } \\
\text { corporate entrepreneurship. }\end{array}$ & $\begin{array}{l}\text { Kuratko, Hornsby e } \\
\text { Covin (2014) }\end{array}$ & Business Horizons & 46 \\
\hline 3 & $\begin{array}{c}\text { Explaining growth paths of young } \\
\text { technology-based firms: structuring resource } \\
\text { portfolios in different competitive } \\
\text { environments. }\end{array}$ & $\begin{array}{l}\text { Clarysse, Bruneel e } \\
\text { Wright (2011) }\end{array}$ & $\begin{array}{l}\text { Strategic } \\
\text { entrepreneurship } \\
\text { Journal }\end{array}$ & 45 \\
\hline 4 & $\begin{array}{l}\text { Imitative innovation strategies Understanding } \\
\text { resource management of competent } \\
\text { followers. }\end{array}$ & $\begin{array}{l}\text { Huang, Chou e Lee } \\
\qquad(2010)\end{array}$ & $\begin{array}{l}\text { Management } \\
\text { Decision }\end{array}$ & 43 \\
\hline 5 & $\begin{array}{l}\text { Offshoring strategy: motives, functions, } \\
\text { locations, and governance modes of small, } \\
\text { medium-sized and large firms. }\end{array}$ & $\begin{array}{l}\text { Roza, Van den Bosch } \\
\text { e Volberda (2011) }\end{array}$ & $\begin{array}{c}\text { International } \\
\text { Business Review }\end{array}$ & 42 \\
\hline 6 & $\begin{array}{l}\text { An empirical study of the relationships } \\
\text { among strategy, flexibility, and performance } \\
\text { in the supply chain context. }\end{array}$ & $\begin{array}{l}\text { Fantazy, Kumar e } \\
\text { Kumar (2009) }\end{array}$ & $\begin{array}{l}\text { Supplay Chain } \\
\text { Management: an } \\
\text { international } \\
\text { journal }\end{array}$ & 40 \\
\hline 7 & $\begin{array}{l}\text { The character of innovative places: } \\
\text { entrepreneurial strategy, economic } \\
\text { development, and prosperity. }\end{array}$ & Feldman (2014) & $\begin{array}{l}\text { Small Business } \\
\text { Economics }\end{array}$ & 32 \\
\hline 8 & $\begin{array}{l}\text { Knowledge strategies for environmental } \\
\text { innovations: the case of Italian manufacturing } \\
\text { firms. }\end{array}$ & $\begin{array}{c}\text { De Marchi e } \\
\text { Grandinetti (2013) }\end{array}$ & $\begin{array}{c}\text { Journal of } \\
\text { Knowledge } \\
\text { Management } \\
\end{array}$ & 28 \\
\hline 9 & $\begin{array}{l}\text { Top management team conflict and } \\
\text { entrepreneurial strategy making in China. }\end{array}$ & Li e Li (2009) & $\begin{array}{l}\text { Asia Pacific } \\
\text { Journal of } \\
\text { Management }\end{array}$ & 27 \\
\hline 10 & $\begin{array}{l}\text { Cash-out or flameout! Opportunity cost and } \\
\text { entrepreneurial strategy: theory, and evidence } \\
\text { from the information security industry. }\end{array}$ & $\begin{array}{l}\text { Arora e Nandkumar } \\
\qquad(2011)\end{array}$ & $\begin{array}{l}\text { Management } \\
\text { Science }\end{array}$ & 26 \\
\hline \multicolumn{4}{|c|}{$\begin{array}{ll} & \text { Total citations } \\
\end{array}$} & 393 \\
\hline
\end{tabular}

The most frequently cited research approaches growth strategies and profitability in the dynamics of young versus old companies. The results found identified relevant 
information, e.g., the young enterprises adopt growth and financial performance strategies more frequently (Steffens, Davidsson and Fitzsimmons, 2009). The topic enables the development of researches that try to understand what the growth strategies are and how they take place, and the supposition that the growth may not reflect the company's performance.

This way, it can be inferred that one of the reasons for the article by Steffens, Davidsson and Fitzsimmons (2009) to be the mostly cited one is the fact the theoretical model developed subsidises future researches about the financial capability and flexibility, and the capability of strategies' discovery, substantially contributing to the strategic entrepreneurship domain.

Table 4 analyses the number of publications developed in collaboration with different institutions.

Table 4. Number of publications by collaboration between institutions.

\begin{tabular}{lcc}
\hline \multicolumn{1}{c}{ Publication forms } & Number of articles & \% \\
\hline Publications with only one author & 9 & 22.5 \\
Publications with authors from the same institution & 13 & 32.5 \\
Publications with authors from 2 different institutions & 13 & 32.5 \\
Publications with authors from 3 different institutions & 4 & 10 \\
Publication with authors from 4 different institutions & 1 & 2.5 \\
\hline Total & $\mathbf{4 0}$ & $\mathbf{1 0 0}$ \\
\hline
\end{tabular}

As for the co-authoring collaborations, it should be highlighted that they can represent interactions among the academic community, which is not the case for the publications with only one author $(22.5 \%)$ and for the publications with authors from the same institution $(32.5 \%)$.

Thus, there are works with two or more distinct institutions, which represent a network of rich inter-institutional collaboration, justified by the volume of connections $(45 \%)$ by observing the total of publications that have between 2 and 4 authors from different institutions.

With the objective to identify the main terms approached in the sample researches, an analysis of the key words was carried out and their Top 10 was catalogued (Table 5).

Table 5. Top 10 of the key words with most representativeness.

\begin{tabular}{cccc}
\hline & Keywords & Number of articles & \% \\
\hline 1 & Innovation & 11 & 5,5 \\
2 & Entrepreneurial strategy & 8 & 4 \\
3 & Entrepreneurship & 4 & 2 \\
4 & Strategy & 3 & 1,5 \\
5 & Performance & 3 & 1,5 \\
6 & Growth & 3 & 1,5 \\
7 & Corporate entrepreneurship & 3 & 1,5 \\
8 & Market & 3 & 1,5 \\
9 & Sustainability & 2 & 1 \\
10 & Corporate social responsibility (CSR) & 1 \\
\hline Total & & 2 & $\mathbf{2 1}$ \\
\hline
\end{tabular}

These results highlight the topics' mapping process efficiency through the analysis of the mostly cited key words. A total of 46 key words were identified, considering the words that were mentioned twice, at least. Thus, the catalogued words in the top 10 represent $21 \%$ of the total words listed in the articles analysed, which means there are several differing key words in the articles investigated, representing the study's particularity and specificity. 
The word "innovation" leads the ranking, which may mean that the articles that come from the 'entrepreneurial strategies' key word outputs may be connected to the innovation factor. The second most representative key word is "entrepreneurial strategy", which was expected, since it was used as the main searching term.

Generally speaking, it can be inferred that these words highlight the involvement of the theme that surrounds the research's topic. The appearance of words such as "market" and "growth" is intrinsically connected to the study's theme context, once the innovative and entrepreneurial strategies involve the market and elicit the organisational growth. Furthermore, it highlights "sustainability" and "corporate social responsibility (CSR)", which shows that these are emerging themes that have an interface with the objects under discussion

\subsection{Beyond Bibliometrics}

\section{Researches that are not directed to the entrepreneurial strategy and innovative strategy}

This item analyzed the 40 articles approached by the bibliometric analysis and is divided into two steps.

Out of the 40 works identified about entrepreneurial strategy and innovative strategy, 20 approach the theme superficially (13 about entrepreneurial strategy and 7 about innovative strategy). In these works, the terms related to the research's theme were cited in a nonintegrated way, that is, in isolated parts of the text, with no connection with the article's analysis object, whether in a central or in a supporting way.

By reading the 13 works related to the entrepreneurial strategy, the reasons that lead them to be discarded were:

Some practices are presented in the works by Monsted \& Hansson (2010), Arora and Nandkumar (2011), Kuratko, Hornsby \& Covin (2014) \& Rokhim et al. (2017), and these practices are defined as entrepreneurial strategies. However, there is no further development about such practice, no explanations about the reasons that lead to this statement, no theoretical basis and there are no models which comprise its structure;

The works by Arribas, Hernández \& Vila (2013), Vorley and Williams (2015), Ching (2016) \& Perry-Rivers (2016) approach the term "entrepreneurial strategy" as a corporate strategy or business strategy, and are not the focus of this study;

In the studies by Clarysse, Bruneel \& Wright (2011), Feldman (2014), Ott, Eisenhardt \& Bingham (2017), Rokhim, et al. (2017) \& Saridakis, Lai \& Mohammed (2018), the term is processed in an isolated way and appears only in the title, as a key word or in the research's conclusion, which shows how disconnected the use of the "entrepreneurial strategy" term is.

As for the 7 works discarded and which are related to the innovative strategy, the reasons for their exclusion were:

Fomba (2009), Grimaldi et al. (2014) \& Kobets \& Yatsenko (2018) bring the innovative strategy term as a booster for the organizations's development. However, with isolated statements and not performing a more systematic and deeper analysis when it comes to such topic;

Some practices on the studies by Okada et al. (2012) are presented as being innovative strategies. However, the text doesn't describe the innovative strategy topic. It only mentions it in some of the article sections individually and superficially;

In the studies by Tipu \& Fantazy (2014), Bocquet et al. (2015) and Fang, Schaumburg \& Fjellström (2017), the term is discussed only once and presented in only one of the study's sections, which shows a lack of the topic's discussion. 


\section{Researches related to the entrepreneurial strategy and innovative strategy}

This item presents some approaches to the researches related to the entrepreneurial strategy and innovative strategy. These works identified elements which comprise future studies' concepts, types, models, trends and gaps, making it important to emphasize that the topics which were this study's object were analyzed in the text in a central way or as a support method for a macro discussion.

\section{Concepts of entrepreneurial strategy and innovative strategy}

Strategy can be defined as the process through which executives craft a set of activities in order to create and capture value, generate missions and objectives, guide the implementation or the integration of resources ( $\mathrm{Li}$ and $\mathrm{Li}, 2009$; Lee and Liu; 2008, and Newbert, 2008). However, in order for the benefits to be enabled, it is necessary that the management coordinates the strategies according to entrepreneurial efforts, with no limits to explore new business opportunities, being placed in a way they can identify the real interest domains for the organization (Kelley, 2011).

New corporate scenarios can be traced through entrepreneurial strategies and/or guided strategies for the innovation (Zhang, 2017).

According to Steffens, Davidsson \& Fitzsimmons (2009), entrepreneurial strategy is the simultaneous search for opportunities and competitive advantage, making the entity's growth and profitability possible. On the other hand, Li \& Li (2009) conceptualizes entrepreneurial strategy as a way to strategy development for the acquisition of the processes, methods and organizational styles, adopted for the strategic decisions' development and implementation.

This way, it is understood that the entrepreneurial strategy searches for the creation of richness by taking risky decisions, innovation and pro-activity, as well as other aspects such as guidance for learning, employees' participation and training (Williams and Lee, 2011).

Studies Developed By Lee \& Liu (2008) Point To Works By Li et al. (2005), Dess, Lumpkin, Covin (1997), Hart (1992) \& Miller (1983), which add that the development of an entrepreneurial strategy involves an attitude or some willingness for the innovation of products, processes and market, commitment, pro-activity, risky decisions and the implementation of new strategies. As observed, the creation of an entrepreneurial strategy encompasses a range of activities performed by the organisations with the objective to formulate and enact strategic missions and goals, including analysis, planning, implementation and decisions, which are indispensable factors for the implementation of this type of strategy and can be a critical tool for the organization's business success.

It should be mentioned that this topic only presented concepts of an entrepreneurial strategy due to the fact that, among the articles analyzed, there were no definitions about innovative strategy.

\section{Types of entrepreneurial strategy and innovative strategy}

As for the types of entrepreneurial strategy, it was possible to identify the off shoring and the corporate types. The article by Roza, Bosch \& Volberda (2011) highlighted the off shoring strategy, a technique that proposes the relocation, which is the displacement of business processes from one country to another and is understood as a macro typology, allocated in the entrepreneurial strategy. Another type of strategy approached by Ireland et al. (2009) and highlighted by Urban (2012) involves the entrepreneurial corporate strategy, disclosed as a reliable perspective by the entire organization, which observes the 
entrepreneurial behavior that purposefully and continually rejuvenates the organization by shaping their operations' scope through entrepreneurial opportunities' appreciation and exploration.

As for the innovative strategies, three of them are highlighted. The first one, structured by Huang, Chou \& Lee (2010), conceptualized as existing organizational resources to improve the innovation capability and developed in three steps: structuring, grouping and leverage activities with the objective to create value during the process. Then, Peñalver et al. (2017) developed and proved the hypothesis that the implementation of practices in CSR has a meaningful and positive influence on the innovation strategy.

Lastly, there is the inclusion of environmental innovation practices by De Marchi \& Grandinetti (2013), who catalogued characteristics for the identification of green innovative companies, which are: (I) having a knowledge strategy that is different from other innovative companies', (II) investing in R\&D continuously, (III) training more their employees with the objective to improve products or services offered, (IV) having a higher valorization of external companies as a source of knowledge on innovation, and (IV) having a wider chain of partners and cooperation with associates.

This way, and having in mind that only four articles presented typologies, it can be inferred that they didn't focus on the types of entrepreneurial strategies and innovative strategies.

\section{Empiric models involving entrepreneurial strategies and innovative strategies}

This topic presents the empiric models that involve entrepreneurial and innovative strategies highlighted by the works analyzed by this research. Seven models were identified. Four of these refer to entrepreneurial strategies and the others refer to innovative strategies, shown as follows.

The first model identified in this research's analysis, directed to the entrepreneurial strategy, was developed by Kelley (2011) and aimed at organizations with low or inadequate entrepreneurial capabilities, as shown in Figure 1.

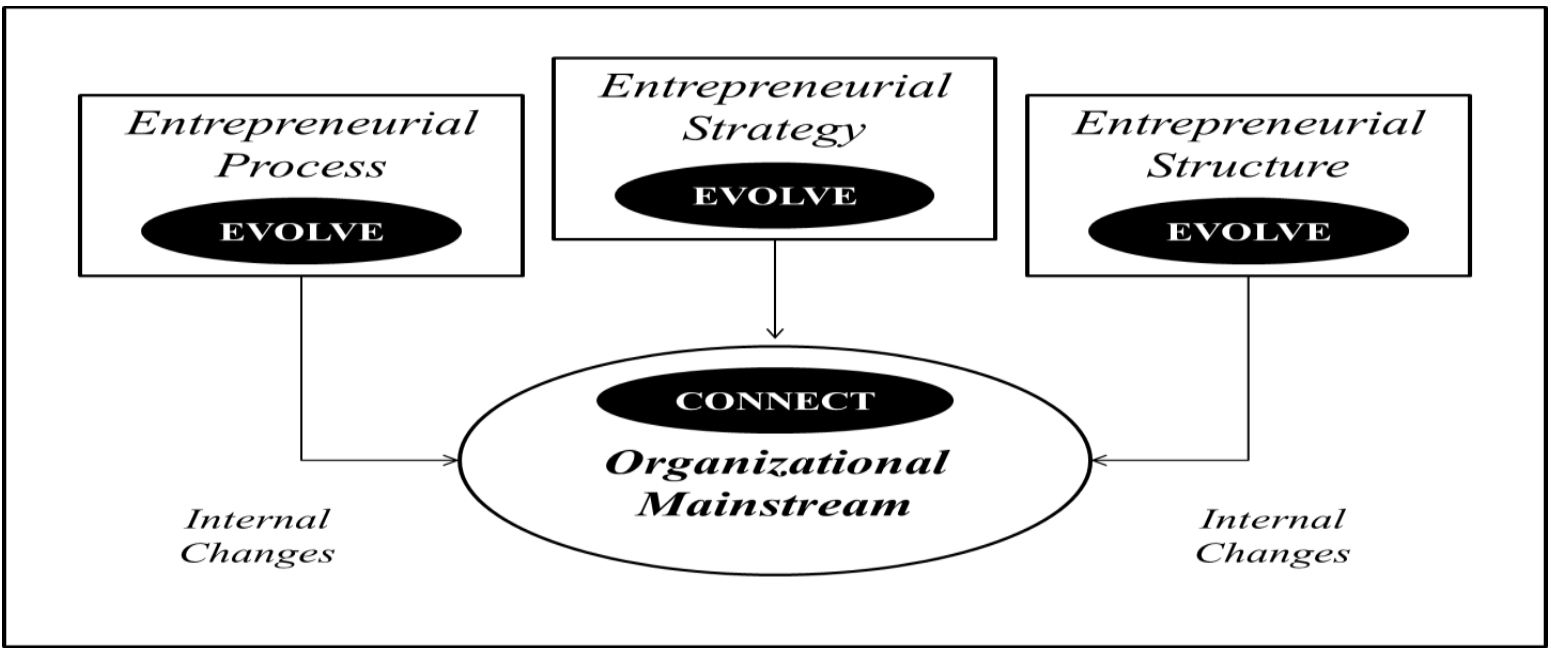

Figure 1. An entrepreneurial strategy model.

Data based on Kelley (2011)

The model was designed to help build and support entrepreneurial capabilities, so that the company may advance in the business market. Thus, it is important to highlight that the conventional organization changes internally and externally by connecting to entrepreneurial 
processes, entrepreneurial strategies and entrepreneurial structures. Following this model, the managers can build up strategies according to structural and processual contexts from each institution, so that there may be improvements and adjustments in the case of developments and changes in the organizational environment.

Then, there is the model designed by Su et al. (2011), who catalogued nine aspects to be observed for determining an entrepreneurial strategy, which are: a strong emphasis on $\mathrm{R} \& \mathrm{D}$; leadership and innovations; changes in the products' line (types/quantity of products); prizing creative solutions instead of conventional ones for the solution of problems; incentive to innovative marketing strategy development; introduction of new products/services, techniques and technologies; the belief that changes enable new market opportunities; incentive for high-risk projects (with very high chances of payback) and development of the actions related to nature and the environment. From the authors' perception, these aspects must be observed upon the adoption of an entrepreneurial strategy.

On the other hand, the study by Wyk \& Adonisi (2011) applied a Corporate Entrepreneurship Assessment Instrument (CEAI) developed in the United States by Hornsby, Kuratko \& Zahra (2002) in a sample of enterprises from South Africa. This instrument evaluates the implementation of a corporate entrepreneurial strategy, structured according to what is described in Figure 2.

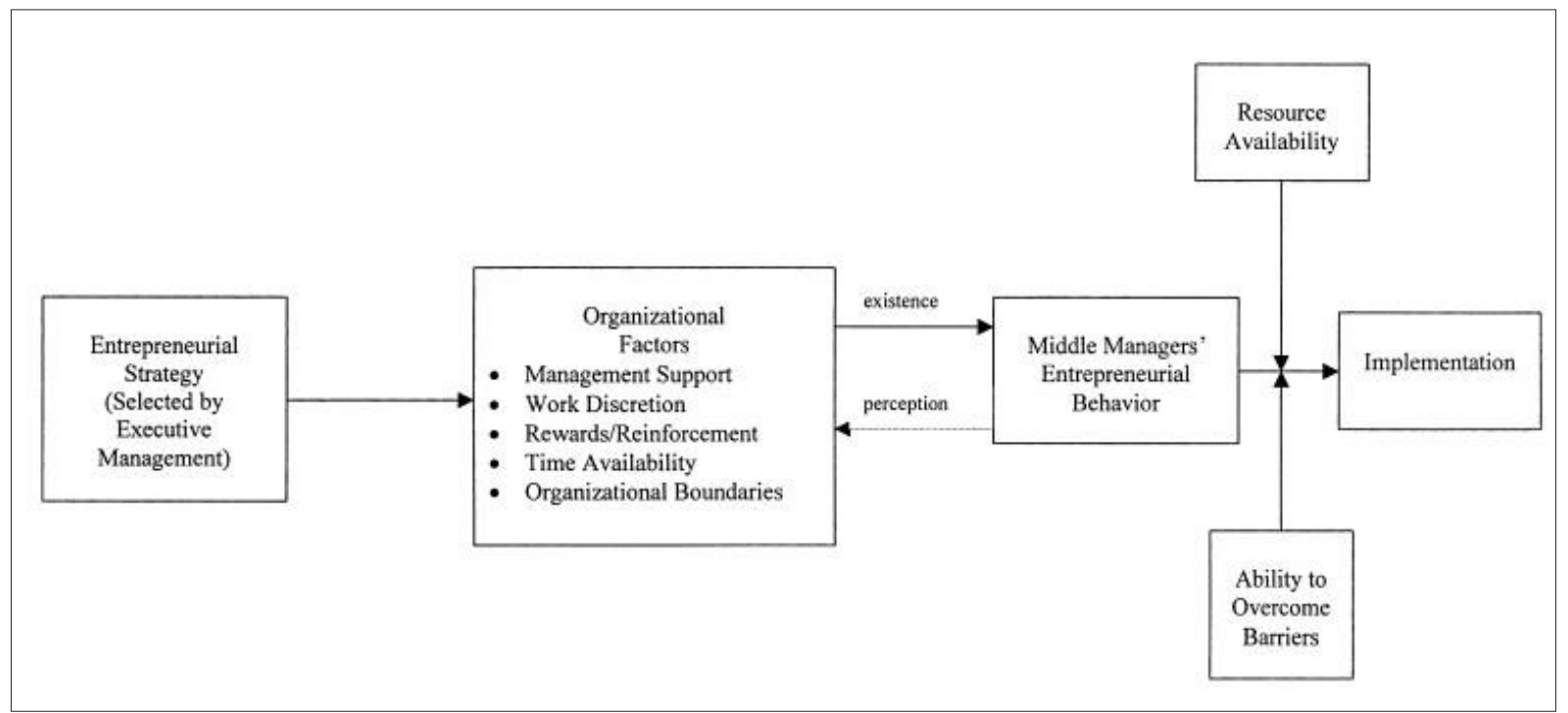

Figure 2. An entrepreneurial strategy model.

Data based on Hornsby, Kuratko and Zahra (2002).

According to this model, these elements must be taken as a basis for the development of an environment that is favorable to the appearance of entrepreneurial strategies. According to Hornsby, Kuratko \& Zahra (2002), this study points out to five stable organizational factors (management support, work discretion/autonomy, reward/support, time availability and organizational limits) which must be acknowledged upon the promotion of the internal organizational elements that lead the managers to promote an entrepreneurial activity.

Through the application of this instrument, the results of the study by Wyk and Adonisi (2011) identified eight factors instead of five, thus concluding that the culture of locality influences the entrepreneurial process' implementation procedure. The new factors were: discretion, management support and risk acceptance, reward/support, innovative initiatives, financial support, time availability, organisational limits and inadequate timing. 
The research by Lee \& Liu (2018) suggests the creation of a business model in which the managers' rationality may attract market opportunities and improve critical factors that are present in the organization, with the objective to mould a competitive advantage. In this model, the entrepreneurial strategy is seen as a moderate power between managerial capability and competitive advantage. Thus, the entrepreneurial strategy is strongly related to the managerial behavior and to the development of strategies connected to the organization's competitiveness, according to Figure 3.

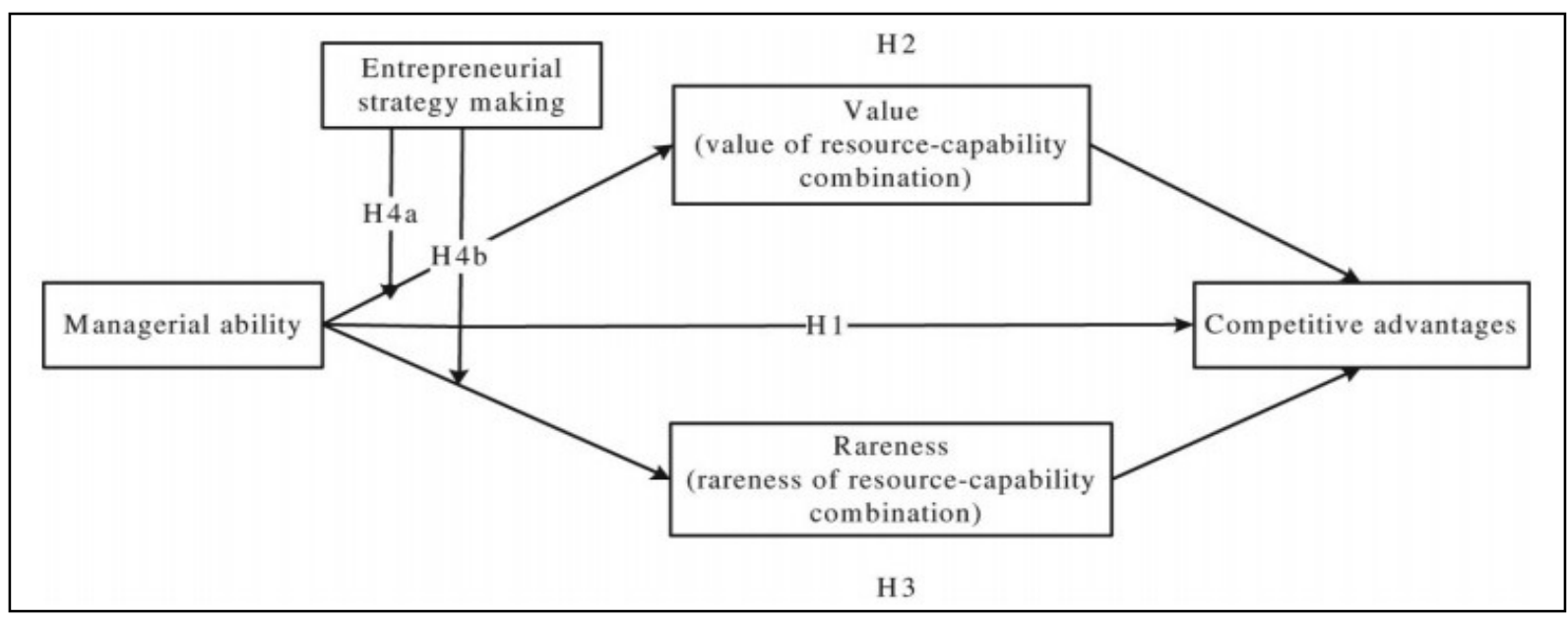

Figure 3. An entrepreneurial strategy model.

Data based Lee and Liu (2018).

As for the empiric model involving innovative strategies, there is the model suggested by Hsieh \& Kung (2011), who carried out a research that employs the Social Cognitive Theory (SCT) and the Fuzzy Theory (FT) along with the Multi-Criteria Decision Making Methodology (MCDM), with the objective to evaluate the hierarchical relations under the light of innovative strategies that involve the labour revolution's domino effect, according to

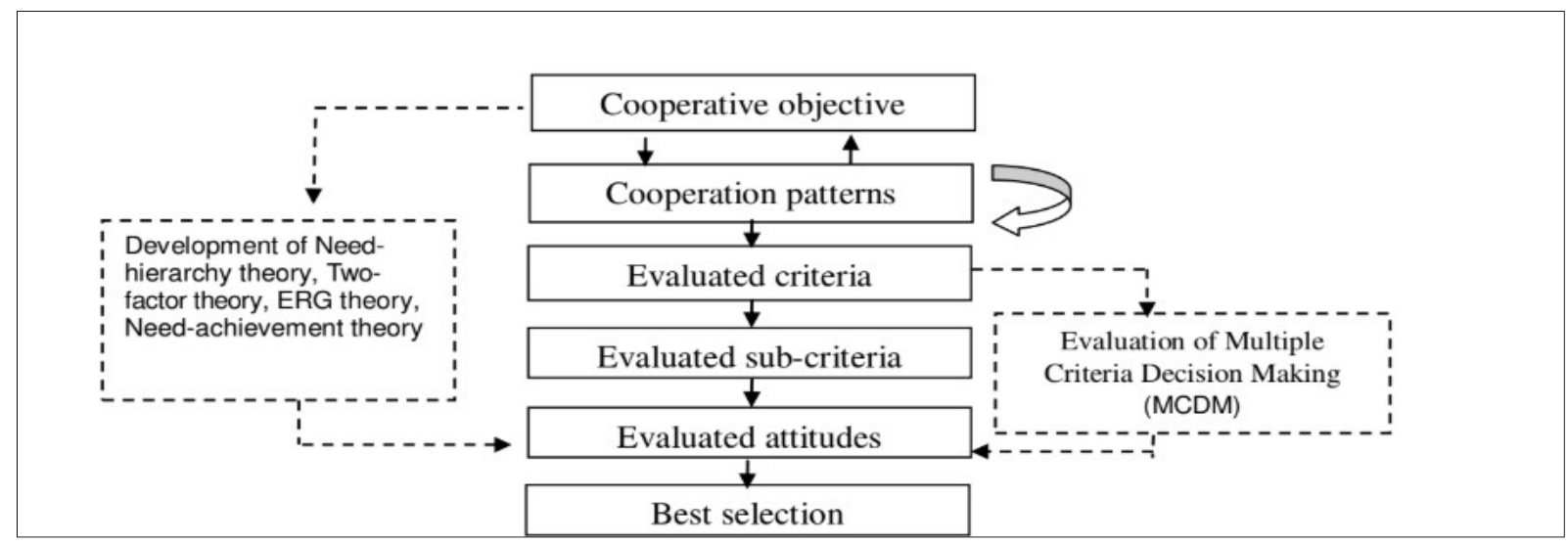

Figure 4. An innovative strategy model.

Data based Hsieh and Kung (2011).

The research's focus consists of selecting the best innovative strategy based on the Multi-Criteria Decision Making Methodology (MCDM). The innovative strategies were related based on the human resources' area and on the hierarchical relationships, which had to adapt to each assessable criterion according to peers' performance. 
Subsequently, the model by Peñalver, Conesa \& Nieto (2017) was observed and it tests the following hypotheses: the implementation of Corporate Social Responsibility (CSR) practices has a meaningful and positive influence on innovation strategy: the CSR has a positive influence on the agribusiness' companies' cooperation; the cooperation positively influences the agribusiness innovation; the agribusiness innovation positively influences the companies' economic performance and the agribusiness cooperation positively influences the companies' economic performance (Figure 5).

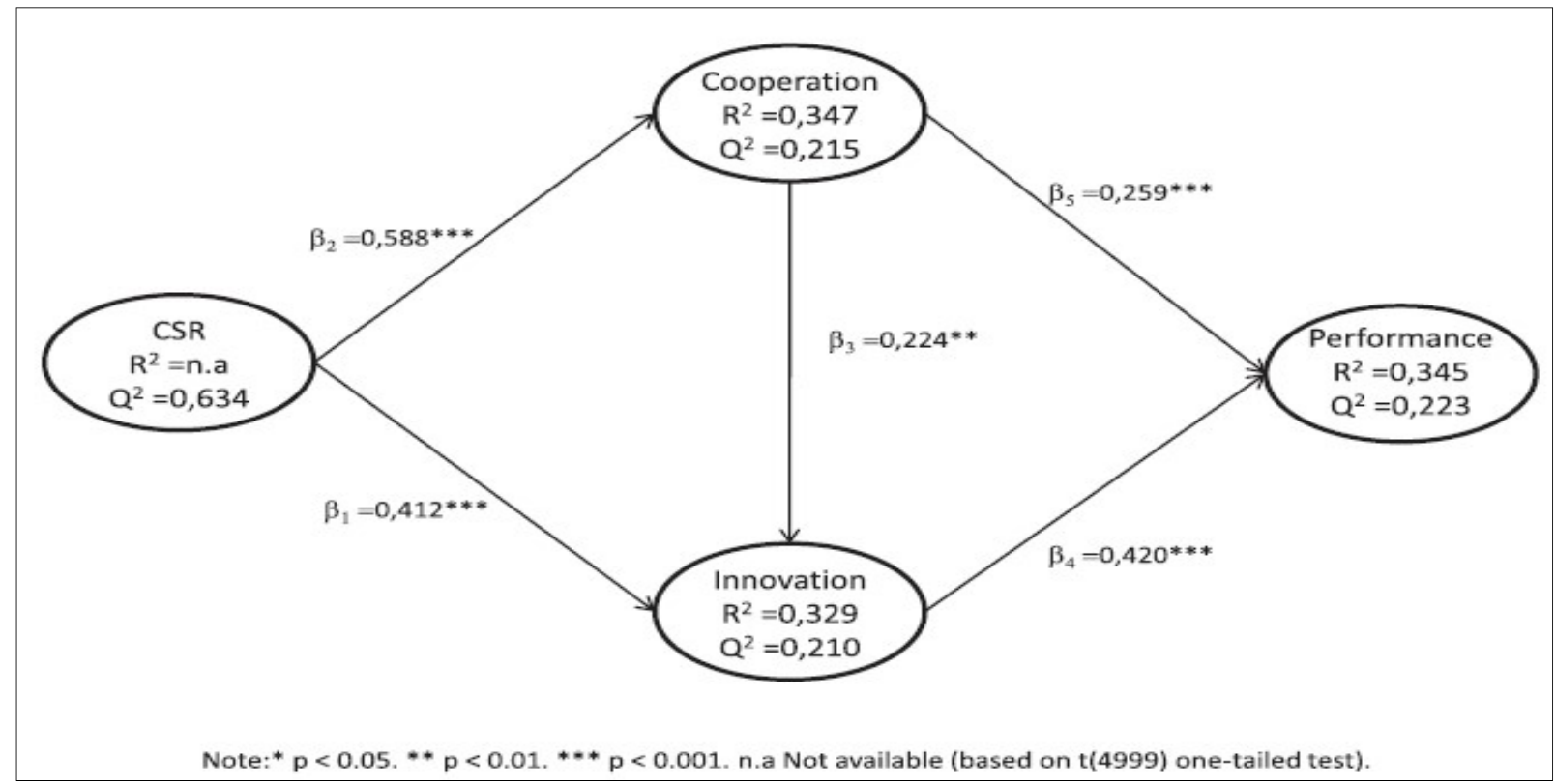

Figure 5. An innovative strategy model.

Data based Peñalver, Conesa and Nieto (2017)

The results after the application of this model show that the hypotheses are accepted, according to the model presented. It should be highlighted that the study's main hypothesis is the approach of the corporate social responsibility as an innovation strategy.

Lastly, Jarrar \& Smith (2014) checked the importance of innovation for companies that follow entrepreneurial strategies of guidance, especially in the implementation of managerial tools. The proposition of the model developed in this research proceeded based on the following hypotheses: innovation provides importance to the use of an inclusive budget in organisations with entrepreneurial strategies (H1a), innovation provides importance to the use of the Balanced Score Card (BSC) in organisations with entrepreneurial strategies (H1b), innovation provides importance to the use of BSC in organisations with entrepreneurial strategies (H1c), innovation provides importance to the use of Total Quality Management (TQM) in organisations with entrepreneurial strategies (H1d), innovation provides importance to the use of Just in Time (JiT) in organisations with entrepreneurial strategies (H1e), \& innovation enables the performance improvement in organisations with entrepreneurial strategies $(\mathrm{H} 2)$. The study hypotheses are represented according to Figure 6. 


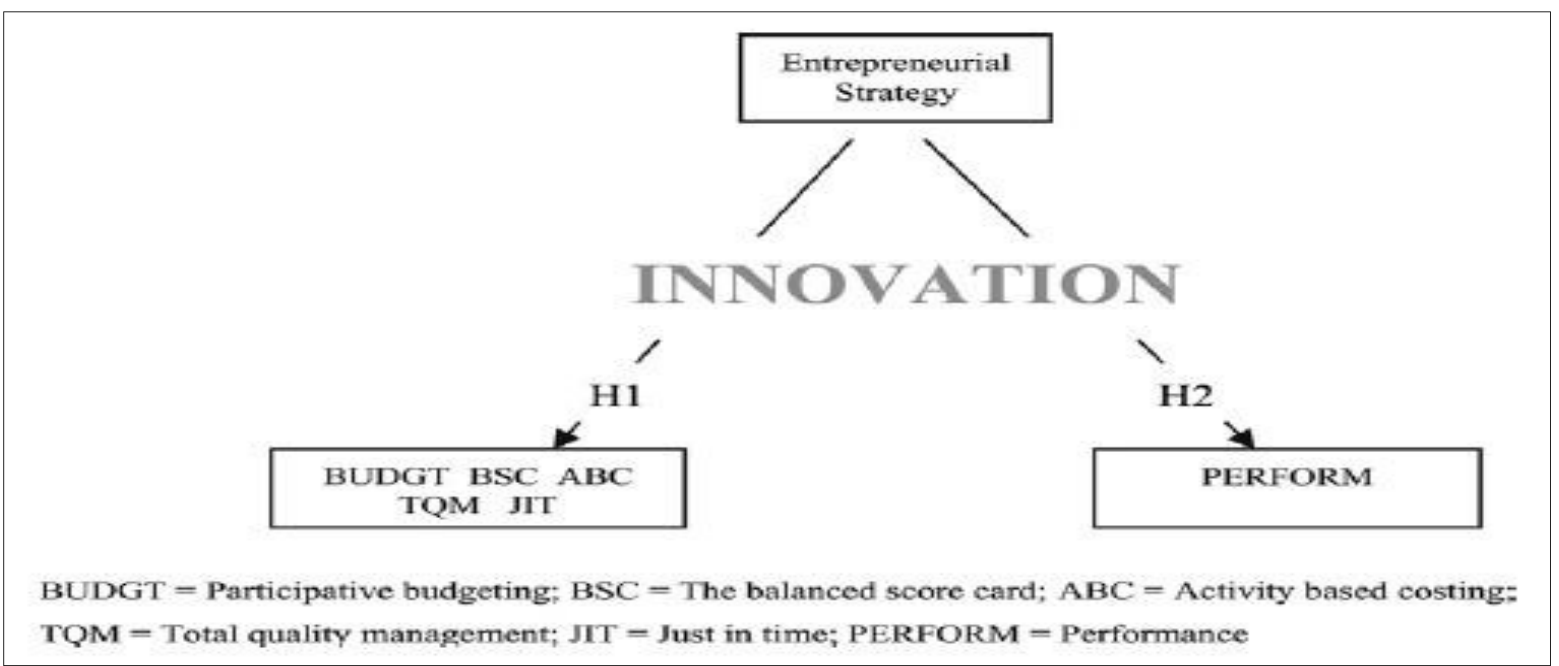

Figure 6. An innovative strategy model.

Data based Jarrar \& Smith (2014).

Based on this model, it is possible to see that only the ABC variable didn't present any significance, which, according to the authors, may be associated with the cost analysis' flexibility. It should be mentioned that this model represents the innovation importance in the companies with entrepreneurial guidance.

Thus, it can be concluded that, from the models presented, there is a great variety of measurement and structuring. However, they converge to the same point, which is the entrepreneurial strategies' process description and innovative strategies.

\section{Study trends on entrepreneurial strategies and innovative strategies}

The research trends presented in the analyzed works used the VOS viewer software to point out the clusters by identifying the words which came up from titles and abstracts, that is, the elements which are somehow directly or indirectly connected.

Four clusters were identified out of the total of 20 terms, besides 136 links or connection occurrence elements, distributed according to Table 6 and through a clusters' map in Figure 7.

Table 6. A clusters' relationship.

\begin{tabular}{|c|c|c|c|}
\hline Cluster 1 (6 items) & Cluster 2 (6 items) & Cluster 3 (4 items) & Cluster 4 (4 items) \\
\hline Author & Article & Firm & Coorporation \\
\hline Family Business & Entrepreneur & Growth & Flexibility \\
\hline Indicador & Entrepreneurship & Profitability & Perfomance \\
\hline Innovativeness & Environment & Time & Relationship \\
\hline Internationalization & Innovative Strategy & & \\
\hline Value & Organization & & \\
\hline
\end{tabular}

Data based on VOS viewer ${ }^{\circledR}(2018)$.

Clusters 1 and 2 deserve some special attention since they highlight more emphatically the terms correlated to this research's topic, such as "innovativeness", "entrepreneur", "entrepreneurship" and "innovative strategy". 


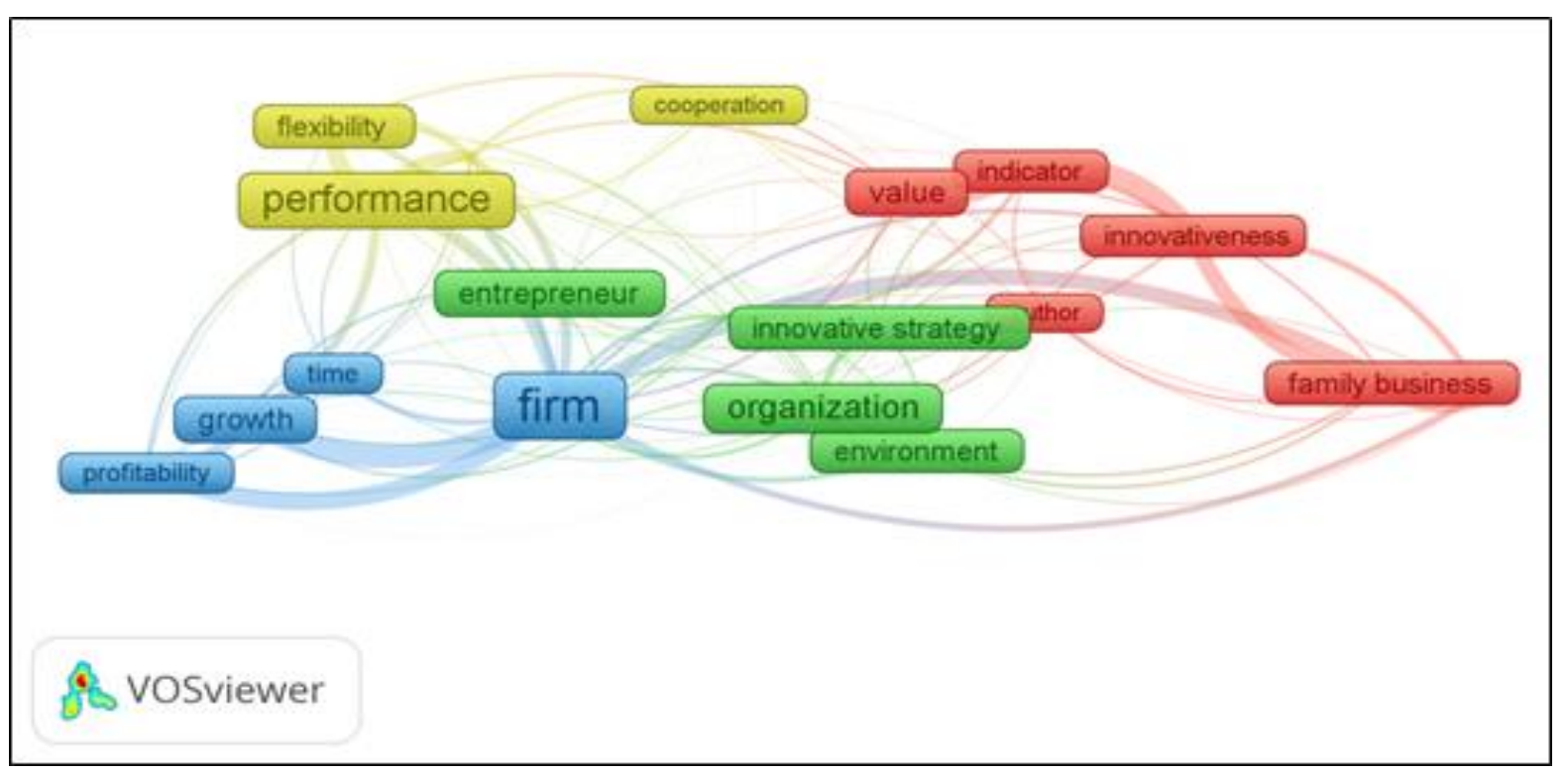

Figure 7. A clusters' map highlighting the occurrence of terms from titles and abstracts. Data based on VOS viewer ${ }^{\circledR}(2018)$.

Cluster 1, represented by the color red, highlights the terms "innovativeness", "internationalization" and the term "family business", showing that some of them analyzed study works on these perspectives. The article that deals with family businesses is the study performed by Singh \& Kota (2017), which approaches a resources' dependency structure for family businesses' innovation and internalization in India, observing these companies' survival and their capacity to develop innovative strategies as a competitive advantage, identifying which family businesses are more innovative and internationalized when compared to non-family businesses. Another highlight is for the younger family businesses, which tend to be even more innovative. This study worked with the resource-based theory and the new learning advantages' theory.

Cluster 2, represented by the color green, brings terms such as "entrepreneurship" and "innovative strategies", showing a connection between these two items. This analysis also highlights the "environment" terminology, speaking about the studies related to the organizations's social responsibility.

The studies which brought up such findings were the ones by Song, Augustine and Yang (2016), highlighting that, in the mine digging sector, the adoption of an environmental innovative strategy in new small size enterprises may help to answer some existing uncertainties in the business market, thus improving the entity's performance. From the environmental innovation perspective, De Marchi \& Grandinetti (2013) brought over a research on knowledge strategies related to the environmental innovation as the capacity to introduce environmental innovation practices like the innovative strategy. On the other hand, Peñalver et al. (2017) approached the social responsibility, bringing in their study's hypothesis the relationship between corporate social responsibility (CSR) and innovation strategy. The authors also defend that studies on innovation and their association with the CSR's measures are becoming more and more common.

Another study's trend identified along the analyses, even if it was not presented in the cluster analysis, was the work by Li \& Li (2009), which examined the conditions under which the high administration's cognitive and affective conflict are associated with the entrepreneurial strategy elaboration, showing the relationship between the top administration, 
the strategies and the organizational performance, and being considered as a trend according to the authors.

\section{Gaps for future studies on entrepreneurial strategies and innovative strategies}

The studies' gaps bring clippings for the development of future works, that is, some perspectives come up for the continuation of studies that involve entrepreneurial strategies and innovative strategies.

The research by Li \& Li (2009) is directed to the development of studies which investigate the dynamic relationship between the attributes and the development of entrepreneurial strategies, by using longitudinal data, due to the fact their study covered a short period of time. Another highlight from the authors is the need for studies which explore the cultural influences in the management team dynamics and how these influences may be connected to the team's strategy relationship.

Wyk \& Adonisi (2011) developed a study in South Africa by applying the Corporate Entrepreneurship Assessment Instrument (CEAI) developed by Hornsby, Kuratko \& Zahra (2002) and which has five factors. However, upon applying the reference study, eight factors were identified, which encourages the improvement of the instrument measurement between cultures, that is, the work points out to the need of validation of the new identified scale and, thus, to the exploration between different cultures.

The research by Hsieh \& Kung (2011) determines the empiric macro-economic data collection as a gap for the study's continuity to create an extensive evaluation model with the objective to develop efficient strategies to survive in the current market.

The theme brought up by Urban (2012) is the corporate entrepreneurship strategy. According to the author, few studies were previously performed using this type of strategy in SMEs. The author also states that proceeding with questioning about the corporate entrepreneurship strategies in an emerging country context is also justifiable as a research gap. This way, small entrepreneurs will be able to understand how the resources and the internal structures contribute to the results.

In the work by De Marchi \& Grandinetti (2013), the study trend was identified through the cluster analysis. However, this can also be seen as a gap for future researches for, according to the authors, few studies approach the environmental innovation in the company's global strategy, dealing with it only as a simple need to follow existing rules. Therefore, the research shows the need of study continuity in this area.

As a gap, Mikolayovich (2015) defends that additional researches should be performed with the objective to investigate the processes' innovative control which are responsible for the innovative stage and for the new products' life cycle.

\section{Final Considerations}

The guided question this research whas: what is there in literature about entrepreneurial strategies, innovative strategies and their possible interfaces encompassing concepts, evolution, gaps and trends?

Therefore, through the analyses of the works were identified, any one concepts of innovative strategy, four concepts of entrepreneurial strategy, three innovative strategy types, two entrepreneurial strategy types, five trends, six gaps and seven models of innovative and entrepreneurial strategy.

As for the concepts involved with the 'entrepreneurial strategy' construct, some works stood out, such as works by Steffens, Davidsson \& Fitzsimmons (2009), Li \& Li (2009), 
Williams; Lee (2001), Lee \& Liu (2008) \& Newbert (2008). In short, entrepreneurial strategy can be understood as a set of activities that are able to create and capture value, guidance and profitability by generating missions and objectives so as to form a competitive advantage, which is essential to developing and implementing strategic-wise decisions. It should also be highlighted that no concepts on innovative strategies were evoked.

As for the entrepreneurial strategy typologies, two of them were identified: off shoring (Roza, Bosch and Volberda, 2011) and corporate (Urban, 2012). As for the innovative strategy, three types of strategies were highlighted: the first one was conceptualised as organisational resources that exist to improve the innovation capacity with the objective to create value during the process (Huan, Chou and Lee, 2010). The second one highlights the supposition that the practices' implementation in CSR has a meaningful and positive influence on the innovation strategy (Peñalver et al., 2017). Lastly, the innovative strategy is the basis for the environmental innovation and points out characteristics for the identification of green entrepreneurial companies (Marchi and Grandinetti, 2013).

Seven models were identified and described. Four of them refer to the entrepreneurial strategies. The first one is directed to the organisations with a low or inadequate entrepreneurial capability (Kelley, 2011); the model by Hornsby, Kuratko and Zahar (2002), which shows five stable factors that must be acknowledged in the promotion process of internal organisational elements; the instrument by Wyk and Adonisi (2011) identifies eight factors which influence the entrepreneurial process, concluding that culture influences entrepreneurship; and the model by $\mathrm{Su}$ et al. (2011), who catalogued nine aspects to be observed in determining an EE, such as R\&D, marketing, leadership and innovation, among others.

As for the models which involve EI, there is the one by Hsieh and Kung (2011), which employs the Social Cognitive Theory (SCT) and the Fuzzy Theory (FT) along with the MultiCriteria Decision Making Methodology (MCDM), with the objective to evaluate the hierarchical relationships under the light of innovative strategies. Then, the model by Peñalver, Conesa \& Nieto (2017), which tests the hypotheses related to the Corporate Social Responsibility (CSR) correlated to innovation. Besides, there is the research by Lee \& Liu (2018), which suggests the creation of a business model in which the managers' rationality can capture market opportunities and improve critical factors in the organisation with the objective to create a competitive advantage. Lastly, the empiric model by Jarrar and Smith (2014) checks the importance of innovation for companies that follow entrepreneurial guiding strategies, especially in the implementation of managerial tools.

Upon analysing the trends, topics such as innovativeness, internationalisation, family businesses, entrepreneurship, innovative strategies and connections between them, social responsibility and environmental innovation were identified.

As for the gaps, the development of studies that try to investigate the dynamic relationship between the Top Management Team (TMT) and the development of entrepreneurial strategies by using longitudinal data; the need to check the new scale in order to improve the instrument measurement between cultures, using the Corporate Entrepreneurship Assessment Instrument (CEAI) as a parameter; the empiric macro-economic data collection for the development of an extensive model of evaluation with the objective to develop efficient strategies to survive in the current market; the environmental innovation approach in the company's global strategy only as the simple need to follow existing rules, among others. Besides, it is important to emphasise that no interfaces between the concepts of entrepreneurial and innovative strategies were identified. 
As limitations, it should be highlighted that the temporal cut focused in the last 10 years and this fact implies on the non-generalisation of the results found. This way, here is a suggestion for future studies which involve topics that go beyond 10 years, enabling the analysis' execution of methodological and theoretical pathways more fully. Besides, here is a recommendation that future researches perform an empiric investigation on the results reached by this bibliometric study.

\section{References}

Alves, M. F. R., Galina, S. V. R. \& Dobelin, S. (2013). Literature on organizational innovation: past and future. Innovation \& Management Review, 15 (1), 2515-896.

Arora, A., \& Nandkumar, A. (2011). Cash-Out or Flameout! Opportunity Cost and Entrepreneurial Strategy: Theory, and Evidence from the Information Security Industry. Management Science, 57 (10), 1844-1860.

Arribas, I., Hernández, P., \& Vila, J. E. (2013). Guanxi, performance and innovation in entrepreneurial service projects. Management Decision, 51 (1), 173-183.

Aslund, A., \& Backtrom, I. (2017). Management processes and management's role in customer value creation.International Journal of Quality and Service Sciences, 9 (2), 148164.

Ávila, L. V., Barros, I. C. F., Madruga, L. R. R. G., \& Schuch Júnior, V. F. (2014). Characteristics of publications on Entrepreneurship (Social) in the Web of Science in the period 2002-2011. Public Administration and Social Management, 6 (2), 88-100.

Bocquet, R., Le Bas, C., Mothe, C. \& Poussing, N. (2015). CSR, Innovation, and Firm Performance in Sluggish Growth Contexts: A Firm-Level Empirical Analysis. Journal of Business Ethics, 146 (1), 241-254.

Brancher, I. B., Oliveira, E. M. De, \& Roncon, A., (2012). Entrepreneurial Behavior: Bibliometric Study of National Production and the Influence of International Theoretical Referential. Electronic Journal of International Business, 7 (1), 166-193.

Ceretta, G. F., Reis, D. R., \& Rocha, A. C. (2016). Innovation and business models: a bibliometric study of scientific production in the Web of Science. Revista Gestão \& Produção, 23 (2), 433-444.

Ching, K. (2016). Exaptation dynamics and entrepreneurial performance: evidence from the internet video industry. Industrial and Corporate Change, 25 (1), 181-198.

Clarysse, B., Bruneel, J., \& Wright, M. (2011). Explaining growth paths of young technology-based firms: structuring resource portfolios in diferente competitive environments. Strategic Entrepreneurship Journal, 5 (2), 137-15. 
Covin, J. G. \& Slevin, D. P. (1989). Strategic management of small firms in hostile and benign environments. Strategic Management Journal, 10 (1), 75-87.

Cruz, I. F. da et al. (2018). Estratégia como prática para o enfrentamento da crise híbrida: um olhar para os praticantes. Revista de Administração, Sociedade e Inovação RASI, 4(2), 140-159.

Dagnino, G. B., Levanti, G., Minà, A., \& Picone, P. M. (2015). Interorganizational network and innovation: a bibliometric study and proposed research agenda. Journal of Business \& Industrial Marketing, 30 (3/4), 354-37.

De Marchi, V., \& Grandinetti, R., (2013). Knowledge strategies for environmental innovations: the case of Italian manufacturing firms. Journal of Knowledge Management, 17 (4), 569-582.

Dess, G. G., Lumpkin, G. T., \& Covin, G. (1997). Entrepreneurial strategy making and firm performance: Tests of contingency and configurational models. Strategic Management Journal, 18 (9), 677-695.

Fang, T., Schaumburg, J., \& Fjellström, D. (2017). International business negotiations in Brazil. Journal of Business \& Industrial Marketing, 32 (4), 591-605.

Fantazy, K. A., Kumar, V., \& Kumar, U. (2009). An empirical study of the relationships among strategy, flexibility, and performance in the supply chain contexto. Supply Chain Management-an International Jornal, 14 (3), 177-188.

Feldman, M. P. (2014). The character of innovative places: entrepreneurial strategy, economic development, and prosperity. Small Business Economics, 43 (1), 9-20.

Fomba, E. M. (2009). Reinforcing experiential learning with training culture as an innovative governance strategy in informal microfinance institutions. International Journal of Technology Management, 45 (1/2), 141-155.

Gomes, A. F. (2004). The entrepreneurial profile of women who conduct their own business: a study in the city of Vitoria da Conquista-BA. Reach Magazine, 11 (2), 207-226.

Global Entrepreneurship Index. (2017). The Global Entrepreneurship and Development Institute, Washington, D.C., USA. Available in: http://ois.sebrae.com.br/publicacoes/indiceglobal-de-empreendedorismo-2017/. Access: 23 mai. 2018.

Global Innovation Index. (2017). Innovation Nourishing the World, Ithaca, Fontainebleau and Geneva.Available in: https://www.globalinnovationindex.org. Access: 23 de mai. 2018.

Grimaldi, M., Cricelli, L., Giovanni, M. D., Rogo, F. (2014). The patent portfolio value analysis: a new framework to leverage patent information for strategic technology planning. Technological Forecasting \& Social Change, 94 (1), 286-302. 
Hart, S. L. (1992). An integrative framework for strategy making processes. Academy of Management Review, 17 (2), 327-351.

Hornsby, J. S., Kuratko, D. F., \& Zahra, S. A. (2002). Middle managers' perception of the internal environment for corporate entrepreneurship: assessing a measurement scale. Journal of Business Venturing, 17 (3), 253-273.

Hsieh, M. Y., \& Kung, C. Y. (2011). Has low-paid advantage of Chinese factory disappeared after the explosion of labor revolution?. African Journal of Business Management, 5 (7), 2723-2733.

Hitt, M. A., Ireland, R. D., Camp, S. M., \& Sexton, D. L. (2002). Strategic Entrepreneurship: Creating a New Mindset.Oxford, UK: Blackwell Publishing.

Huang, J. Y., Chou, T. C., \& Lee, G. G. (2010). Imitative innovation strategies Understanding resource management of competent followers. Management Decision, 48 (5), $952-975$.

Ireland, R. D., \& Webb, J. W. (2007). Strategic entrepreneurship: creating competitive advantage through streams of innovation, Business Horizons, 50 (1), 49-59, 2007.

Jarrar, N. S., \& Smith, M. (2014). Innovation in entrepreneurial organisations: a platform for contemporary management change and a value creator. The British Accounting Review, 46 (1), 60-76, 2014.

Jassen, M., \& Moors, E. H. M. (2013). Caring for healthcare entrepreneurs Towards successful entrepreneurial strategies for sustainable innovations in Dutch healthcare. Technological Forecasting \& Social Change, 80 (7), 1360-1374.

Kelley, D. (2011). Sustainable corporate entrepreneurship: Evolving and connecting with the organization. Business Horizons, 54 (1), 73-83.

Kobets, V., \& Yatsenko, V. (2018). What can economic experiments discover about evolutionary effectiveness of supermarket strategies? Marketing and Management of Innovations, 1, 152-168.

Kuratko, D. F., Hornsby, J. S., \& Covin, J. G. (2014). Diagnosing a firm's internal environment for corporate entrepreneurship. Business Horizons, 57 (1), 37-47.

Lee, T., \& Liu, H. M. (2018). How do Firms with Management Ability Promote Competitive Advantages? An Integrated Model from Entrepreneurial Strategy Making and Internal Resources. Entrepreneurship Research Jornal, 8 (2), 1-15.

Li, H. Y., \& Li, J. (2009). Top management team conflict and entrepreneurial strategy making in China. Asia Pacific Journal of Management, 26 (2), 263-283. 
Li, H., Zhang, Y., \& Chan, T. (2005). Entrepreneurial strategy making and performance in China's new technology ventures: The contingency effect of environments and firm competences. Journal of High Technology Management Research, 16 (1), 37-57.

Song, L., L., Augustine, D., \& Yang, J. Y. (2016) Environmental uncertainty, prospector strategy, and new venture performance: the moderating role of network capabilities. International Entrepreneurship and Management Journal, 12, 1103-1126.

Maculan, A. M. (2005). Technological capacity and innovation in Brazilian companies: balance and perspectives. Cad. EBAPE.BR, 3, 1-18.

Mikolayovich, S. I. (2015). Innovative process rational choice grounding in organization. Маркетингінновацій,2, 11-20.

Miller, D. (1983). The correlates of entrepreneurship in three types of firms.Management Science, 29, 770-791.

Monsted, M., \& Hansson, F. (2010). Creating Space for Research: The Charismatic Entrepreneur as Research Director. Creativity and Innovation Management, 19(1), 47-56.

Narasimhan, R., Kull, T. J., \& Nahm, A. (2012). Alternative relationships among integrative beliefs, time- based manufacturing and performance. International Journal of Operations \& Production Management, 32 (4), 496-524.

Newbert, S. L. (2008). Value, Rareness, Competitive Advantage, and Performance: a conceptual level empirical investigation of the resource. Strategic Management Journal,2 (9), 745-768.

Okada, N., Na, J., Fang, L. Teratani, A. (2013). The Yonmenkaigi System Method: an implementation-oriented group decision support approach, Group Decision and Negotiation, $22(1), 53-67$.

Oliveira, A. B., Rodrigues, R. S., \& Matias, M. (2017). Scientific journals of Agrarian Sciences: analysis of Brazilian indexed titles in the Web of Science and Scopus. Perspectivas emCiências daInformação,22 (2), 3-28.

Ott, T. E., Eisenhardt, K. M., \& Bingham, C. B. (2017). Strategy Formation in Entrepreneurial Settings: Past Insights and Future Directions. Strategic Entrepreneurship Journal, 11 (3), 306-325.

Peñalver, A. J. B., Conesa, J. A. B., \& Nieto, C. N. (2017). Analysis of corporate social responsibility in Spanish agribusiness and its influence on innovation and perfomance. Corporate Social Responsibility and Environmental Management, 25 (2), 182-193. 
Perry-River, P. (2017). Stratification, economic adversity, and entrepreneurial launch: the effect of resource position on entrepreneurial strategy.Entrepreneurship Theory and Pratice, 40 (3), 685-712.

Rokhim, R., Wahyuni, S., Wulandari, P., \& Ayu, F. (2017). Analyzing key success factors of local economic development in several remote areas in Indonesia.Journal of Enterprising Communities-people and places of global economy. 11 (4), 438- 455.

Roza, M., Van den osch, F. A. J., \& Volberda, H. W. (2011). Offshoring strategy: Motives, functions, locations, and governance modes of small, medium-sized and large firms. International Business Review, 20 (3), 314-323.

Saridakis, G., Lai, Y. Q., Mohammed, A. M., \& Hansen, J. M. (2018) Industry characteristics, stages of E-commerce communications, and entrepreneurs and SMEs revenue growth. Technological Forecasting And Social Change, 128, 56-66.

Schumpeter, J. (1982). Theory of economic development (The Economists): an investigation of profits, capital, credit, interest and the economic cycle. Introduction by Rubens Vaz da Costa. Translated by Maria Sílvia Possas. São Paulo: Cultural April.

Severo, E. A. et al. (2019). Vamos expandir um negócio inovador? Caso de ensino. Revista de Administração, Sociedade e Inovação - RASI, 5(1), 77-90.

Silva, M. R., Hayashi, C. R. M., \& Hayashi, M. C. P. I. (2011). Bibliometric and scientometric analysis: challenge for specialists working in the field. InCID: Revista de Ciência da Informação e Documentação, 2 (1), 110-129.

Singh, R., \& Kota, H. B. (2017). A resource dependency framework for innovation and internationalization of family businesses Evidence from India. Journal of Entrepreneurship in Emerging Economies, 9 (2), 207-231.

Song, L., Augustine, D., \& Yang, J. Y. (2016). Environmental uncertainty, prospector strategy, and new venture performance: the moderating role of network capabilities. International Entrepreneurship and Management Journal, 12(4), 1103-1126.

Su, Z. F., Xie, E., Wang, D., \& Li, Y. A. (2011). Entrepreneurial strategy making, resources, and firm performance: evidence from China. Small Business Economics, 36 (1), 235-247.

Spekman, R., \& Davis, E. W. (2016). The extended enterprise: a decade later.International Journal of Physical Distribution \& Logistics Management, 46 (1), 43-61.

Steffens, P., Davidsson., P \& Fitzsimmons, J. (2009). Performance Configurations Over Time: Implications for Growth- and Profit-Oriented Strategies. Entrepreneurship theory and practice, 33 (1), 125-148. 
Tipu, S, A, A., \& Fantazy, K. A. (2014). Supply chain strategy, flexibility, and performance: A comparative study of SMEs in Pakistan and Canada. The International Journal of Logistics Management, 25 (2), 399-416.

Tondolo, V. A. G., Bitencourt, C. C., \& Tondolo, R. R. P. (2011). Implementation of international entrepreneurial strategy in the wine sector: the case of the Miolo Winery. Organizações Rurais \& Agroindustriais, 13 (3), 363-376.

Urban, B. (2012). The effect of pro-entrepreneurship architecture on organisational outcomes. Journal of Business Economics and Management, 13 (3), 518-545.

Velasquez, J. L., Dalla Santa, E., D. \& Dias, T. (2016). Innovation and entrepreneurship: a study bibliometric of articles published in the period 2003 to 2013. Revista da UNIFEBE, Brusque, 19 (1), 86-103.

Vorley, T., \& Williams, N. (2015). Between petty corruption and criminal extortion: how entrepreneurs in Bulgaria and Romania operate within a devil's circle. International Small Business Journal, 34 (6), 797-817.

Yeo, W. et al. (2015). A bibliometric method for measuring the degree of technological innovation. Technological Forecasting \& Social Change, 95, 152-162.

Wang, E. S., \& Juan, P. (2016). Entrepreneurial Orientation and Service Innovation on Consumer Response: A B\&B Case. Journal of Small Business Management, 54 (2), 532-545.

Williams, C., \& Lee, S. H. (2011). Political Heterarchy and Dispersed Entrepreneurship in the MNC. Journal of Management Studies, 48 (6), 1243-1268.

Wyk, R., \& Adonisi, M. (2011). An eight-factor solution for the Corporate Entrepreneurship Assessment Instrument. African Journal of Business Management, 5 (8), 3047-3055.

Zhang, H. N. (2017). Complexity Absorption: A Processual Strategic Approach To Corporate Entrepreneurship Strategy. Frontiers Of Business Research In China, 11 (3), 1-20. 